\title{
HUBUNGAN PENGETAHUAN REMAJA TENTANG SEKS DENGAN PRILAKU SEKSUAL PADA REMAJA DI SMA N 21 KOTA BATAM TAHUN 2019
}

\author{
Ika Novita Sari ${ }^{1}$, Susanti $^{2}$ \\ Prodi IImu Keperawatan dan Prodi Kebidanan D-3 Fakultas Kedokteran \\ Universitas Batam \\ 1 ikanovitasari@univbatam.ac.id \\ 2susanti.1187@gmail.com
}

\begin{abstract}
ABSTRAK
Hasil survei tahun 2012 oleh Komisi Penanggulangan AIDS Provinsi Kepulauan Riau menunjukkan hanya $22 \%$ yang membuktikan pengetahuan komprhensif remaja. Menurut BKKBN (2016) 46\% remaja usia 15-19 tahun di Indonesia pernah melakukan hubungan seks, angka kehamilan di usia muda mencapai 500 ribu remaja perempuan dimana $30 \%$ diantaranya memilih untuk melakukan aborsi. Penelitian ini bertujuan untuk mengetahui apakah ada hubungan pengetahuan Remaja tentang seks dengan perilaku seksual pada remaja. Desain penelitian yang digunakan cross sectional. Penelitian ini melibatkan 59 partisipan siswa/i yang diseleksi dengan tekhnik slovin. Instrumen yang digunakan adalah kuesioner. Hasil penelitian menunjukkan ada hubungan antara pengetahuan remaja tentang seks dengan prilaku seksual pada remaja di SMA Negeri 21 Kota Batam Tahun $2019(p<0,05)$. Untuk menangani masalah perilaku seksual yang negatif, perlu diadakan program kesehatan reproduksi pada remaja dan bekerjasama dengan orang tua untuk memperhatikan siswa/i.
\end{abstract}

Kata kunci : Pengetahuan remaja tentang seks, Perilaku seksual, remaja

\begin{abstract}
The 2012 survey by the AIDS relief commission in the riau islands province shows only 22\% that prove the cumulative knowledge of youth according to BKBN (2016) $46 \%$ of young teenagers 15-19 in Indonesia have had sexual intercourse at the young age of 500 thousand teenage girls where $30 \%$ of $30 \%$ of households chose to have an abortion. The study aims to find out if there is a teenage knowledge of sex with sexual behavior in teenagers. The design of the study used at sectionals involved 59 student participants selected by the slovin technique. An instrument is a questionnaire. Research shows there is a link between the teen knowledge of sex and sexual behavior in a teenager at batam 21 state high school in 2019 ( $p<0.05)$. To deal with negative sexual behavior problems, there needs to be an inducing health program in youth and cooperation with parents to look after students.
\end{abstract}

Keyword : Adoleccent knowledge about sex, sexual behavior, adolescents 


\section{PENDAHULUAN}

Menurut World Health Organization (WHO), remaja adalah penduduk dalam rentang usia 10-19 tahun, menurut Peraturan Menteri Kesehatan Republik Indonesia Nomor 25 tahun 2014 remaja adalah penduduk dalam rentang usia 1018 tahun, sedangkan menurut Badan dan Koordinasi Keluarga Berencana Nasional (BKKBN) rentang usia remaja adalah 10 sampai 24 tahun. Masa Remaja merupakan periode terjadinya pertumbuhan dan perkembangan yang pesat baik dari fisik, psikologis maupun intelektual. Remaja memiliki sifat yang khas, yaitu memiliki rasa keingintahuan yang tinggi, menyukai petualangan dan tantangan serta berani menanggung segala macam resiko atas perbuatannya tanpa berpikir panjang. Apabila keputusan yang diambil tidak tepat, mereka akan terjerumus ke dalam perilaku beresiko (Pusat Data dan Informasi Kementerian Kesehatan RI, 2015) dalam (Yudia, Cahyo, \& Kusumawati, 2018).

Jumlah penduduk remaja di dunia yang berusia 10-19 tahun menurut WHO adalah sekitar 1,2 milyar (Pusat Data dan Informasi Kementrian Kesehatan RI, 2012). Setiap tahun diperkirakan 21 juta anak perempuan berusia 15 hingga 19 tahun dan 2 juta anak perempuan di bawah 15 tahun hamil di daerah berkembang Sekitar 16 juta anak perempuan berusia 15 hingga 19 tahun dan 2,5 juta anak perempuan di bawah usia 16 tahun melahirkan di daerah berkembang. Tingkat kelahiran remaja global telah menurun dari 65 kelahiran per 1000 wanita pada 1990 menjadi 47 kelahiran per 1000 wanita pada 2015. Terlepas dari kemajuan keseluruhan ini, karena populasi global remaja terus tumbuh, proyeksi menunjukkan jumlah kehamilan remaja akan meningkat secara global pada tahun 2030. (WHO,2018).

Kunjungan balita ke Posyandu adalah datangnya balita ke Posyandu untuk mendapatkan pelayanan kesehatan misalnya penimbangan, imunisasi, penyuluhan gizi, dan lain sebagainya. Kunjungan balita ke Posyandu paling baik adalah teratur setiap bulan atau 12 kali pertahun. Untuk ini kunjungan balita diberi batasan minimal $8 x$ dalam setahun yang tercatat di Kohort anak Balita, buku $\mathrm{KIA} / \mathrm{KMS}$, atau buku pencatatan dan pelaporan lainnya.

Di Indonesia jumlah penduduk remaja berusia 10-19 tahun berdasarkan proyeksi Badan Perencanaan Pembangunan Nasional (Bappenas) adalah 45.122.200 jiwa (Databoks, 2018). Badan kependudukan dan keluarga berencana (BKKBN) menilai, perkembangan isu remaja khususnya prilaku remaja akhir akhir ini di Batam sudah mengindikasi kearah prilaku beresiko. Hal tersebut terlihat berdasarkan survei kesehatan reproduksi remaja (SKKR) tahun 2012 yang dilakukan oleh BKKBN.

Menurut (Jatmika, 2010) rasa ingin tahu seksual dan coba - coba pada remaja adalah bagian yang normal dari perkembangan remaja itu sendiri. Rasa ingin tahu seksual dan birahi jelas menimbulkan perilaku seksual. pacaran dan perilaku seksual adalah sesuatu yang tidak dapat dipisahkan, remaja sedang mencari jati diri membuat rasa keingintahuan mereka besar salah satunya seksualitas.

Tujuan penelitian ini untuk mengetahui Di ketahuinya hubungan pengetahuan Remaja tentang seks dengan perilaku seksual pada remaja di SMA N 21 Kota Batam.

\section{METODE PENELITIAN}

Penelitian ini menggunakan desain Cross Sectional, dilaksanakan di SMA N 21 Kota Batam pada bulan April-Agustus 2019. Populasi siswa/i kelas XI-XII IPS sebanyak 145 anak, teknik pengambilan sampel menggunakan rumus slovin. Instrumen penelitian menggunakan kuesioner. Data di olah menggunakan sistem komputerisasi 


\section{HASIL DAN PEMBAHASAN}

Hasil yang ditampilkan terdiri dari hasil analisis univariat dan analisis bivariat. Tabel 1 memaparkan mayoritas remaja pengetahuan tentang seksnya kuran dan perilaku seksualny negatif.

Tabel 1. Distribusi frekuensi karakteristik

\begin{tabular}{clccc}
\multicolumn{5}{c}{ responden } \\
\hline No & Karakteristik & Kategori & $\boldsymbol{f}$ & $\%$ \\
\hline 1 & Pengetahuan & Baik & 23 & 39 \\
& Seksual & Kurang Baik & 36 & 61 \\
& & Jumlah & 59 & 100,0 \\
\hline 2 & Perilaku & Positif & 19 & 32,2 \\
& Seksual & Negatif & 40 & 67,8 \\
& & Jumlah & 59 & 100,0 \\
\hline
\end{tabular}

Tabel 2. Hubungan pengetahuan remaja tentang seks dengan prilaku seksual pada remaja di SMA Negeri 21 Kota Batam Tahun 2019

\begin{tabular}{|l|c|c|c|c|c|c|c|}
\hline \multirow{2}{*}{$\begin{array}{l}\text { Pengetahuan } \\
\text { Seksual }\end{array}$} & \multicolumn{4}{|c|}{ Perilaku Seksual } & \multicolumn{2}{|c|}{ Total } & \multirow{2}{*}{$\begin{array}{c}p \\
\text { value }\end{array}$} \\
\cline { 2 - 7 } & \multicolumn{2}{|c|}{ Positif } & \multicolumn{2}{|c|}{ Negatif } & \multicolumn{2}{|c|}{} \\
\cline { 2 - 6 } & $\mathrm{f}$ & $\%$ & $\mathrm{f}$ & $\%$ & $\mathrm{n}$ & $\%$ & \\
\hline Baik & 14 & 23,73 & 9 & 15,25 & 23 & 39 & \\
\hline Kurang baik & 5 & 8,48 & 31 & 52,54 & 36 & 61 & 0,000 \\
\hline & 19 & 32,21 & 40 & 67,79 & & 100 & \\
\hline
\end{tabular}

Berdasarkan hasil uji statistik yang disajikan pada tabel 2 dapat disimpulkan bahwa terdapat hubungan antara pengetahuan remaja tentang seks dengan perilaku seks $(p<0,05)$.

Dari hasil analisis univariat pengetahuan tentang seksual remaja dalam penelitian ini adalah kurang baik. Hasil penelitian ini sejalan dengan penelitian yang dilakukan oleh Egy Pratama terhadap remaja di SMA Z Kota Bandung dengan hasil remaja yang berpendidikan kurang baik.

Pengetahuan tentang seks menurut Mariana sesungguhnya adalah pemahaman tentang diri kita sendiri, bukan mengajarkan tentang cara berhubungan seks. Kurangnya pengetahuan tentang seks berdampak pada perilaku seks negatif yang mengakibatkan tingginya tingkat penularan Penyakit Menular Seksual (PMS) seperti HIV/AIDS. Dampak negatif lainnya yaitu tingginya pergaulan bebas terutama di kota besar, merebaknya pelacuran, hingga banyak remaja yang hamil di luar nikah, bahkan menggugurkan kandungannya.
Perilaku seksual seringkali diartikan salah oleh orang dengan hubungan seksual. Perilaku seksual terbagi menjadi dua : perilaku seks positif dan perilkau seks negatif. Perilaku seksual di dasari oleh dorongan seksual atau keinginan untuk mendapatkan kesenangan organ seksual melalui berbagai perilaku. Perilaku seksual tersebut sangat luas sifatnya, mulai dari berdandan, mejeng, merayu, menggoda hingga aktifitas hubungan seksual. Dari hasil penelitian ditemukan bahwa mayoritas remaja memiliki perilakuk seksual negatif.

Hasil penelitian sejalan dengan penelitian yang dilakukan oleh Fitriani tentang perilaku seksual pada remaja di SMK Prayatna-1 Medan, dengan hasil perilakunya negatif sebanyak $56,1 \%$.

Berdasarkan analisa bivariat, hasil penelitian ini menunjukkan ada hubungan yang signifikan antara pengetahuan remaja tentang seks dengan perilaku seksual pada remaja di SMAN 21 Kota Batam. Hasil penelitian ini sejalan dengan temuan Wulan di SMA N 11 Yogyakarta yang meneliti hubungan pendidikan seks dengan perilaku seksual siswa kelas X SMA N Yogyakarta tahun 2011. Penelitian tersebut menemukan bahwa responden yang mempunyai pendidikan seks rendah mempunyai kecenderungan untuk mempunyai perilaku seks beresiko.

Berbeda dengan penelitian yang dilakukan oleh Febrian Firza mengenai hubungan antara pengetahuan remaja tentang pendidikan seksualdengan perilaku seksual pranikah pada remaja. Penelitian tersebut menemukan bahwa pengetahuan remaja tentang pendidikan seks tidak selalu menjadi pemicu terhadap terjadinya perilaku seksual.

Penelitian ini sesuai dengan pendapat Glevinno (2008) yang mengatakan bahwa pemberian informasi masalah seksual sangat penting bagi remaja terlebih lagi mengingat remaja berada dalam potensi seksual yang aktif, karena berkaitan dengan dorongan seksual yang dipengaruhi hormon dan tidak cukupnya informasi mengenai 
aktifitas seksual mereka sendiri. Tentu saja hal tersebut akan sangat berbahaya bagi perkembangan jiwa remaja bila tidak didukung dengan pengetahuan dan informasi yang tepat

\section{KESIMPULAN}

Simpulan yang dapat diambil dari penelitian ini antara lain, dari 59 partisipan yang terdiri dan siswa/i kelas XI-XII IPS, mayoritas mempunyai pengetahuan tentang seks kurang baik dan perilaku seks negatif.

Berdasarkan analisis bivariat dapat disimpulkan bahwa terdapat hubungan yang signifikan antara pengetahuan remaja tentang seks dengan perilaku seksual pada remaja di SMAN 21 Kota Batam $(p<0,05)$

\section{DAFTAR PUSTAKA}

Anonim (2017a) "Pernikahan Dini di Kepri," Batampos.co.id, 17 April. Tersedia pada: https://batampos.co.id/2017/04/17/ pernikahan-dini-di-kepri/.

Anonim (2017b) Saatnya Terjun ke Bisnis Digital, Batampos.co.id.media-sosial-iniaplikasi-yang-digunakan.

Databoks (2018) 2018 , Jumlah Penduduk Indonesia Mencapai 265 Juta Jiwa.

Hootsuite (2019) Digital 2019 Indonesia. Tersedia pada: https://datareportal.com/reports/dig ital-2019-indonesia (Diakses: 16 Maret 2019).

Jatmika, S. (2010) Genk remaja, Anak Haram Sejarah Ataukah Hasil Globalisasi ? Yogyakarta: Kanisius.

Kementrian Pemberdayaan Perempuan dan Perlindungan Anak (2018)
PATBM Basis Wujudkan Internet Ramah Anak. Tersedia pada: file:///C:/Users/asus/Downloads/ko munitas/artikel $\mathrm{kti}$ fikseu/kementrian pemberdayaan perempuan dan perlindungan anak.html (Diakses: 16 Maret 2019).

Khairuni, N. (2016) "Dampak Positif dan Negatif Sosial Media Terhadap Pendidikan Akhalak Anak," Education, 2(1).

Lapau, B. (2015) Metodologi Penelitian Kebidanan. Jakarta: Yayasan Pustaka Obor Indonesia. Tersedia pada:

https://books.google.co.id/books?id $=-$

x9IDAAAQBAJ\&pg=PA307\&dq=an alisis+univariat+metodologi+penelit ian\&hl=en\&sa=X\&ved=0ahUKEwjf y8vE1JPhAhXEul8KHYX1BT8Q6A $E I K j A A \# v=$ onepage $\& q=$ analisis univariat metodologi penelitian\&f=false.

Lestari, T. (2015) Kumpulan Teori Untuk Kajian Pustaka Penelitian Kesehatan. Yogyakarta: Nuha Medika.

Miswanto (2018) "Seks Berisiko di Kalangan Remaja," Tanjung Pinang Pos, 24 Februari. Tersedia pada:

http://tanjungpinangpos.id/seksberisiko-di-kalangan-remaja/.

Notoatmodjo, S. (2011) Kesehatan Masyarakat Ilmu dan Seni. Jaka: Rineka Cipta.

Pusat Data dan Informasi Kementrian 
Kesehatan RI (2012) Situasi Kesehatan Reproduksi Remaja. Jakarta.

Rumengan, J. (2010) Metodologi Penelitian dengan SPSS. Batam.

Sari, A. F. (2018) Hubungan Pengetahuan dan Sikap Tentang Kesehatan Reproduksi dengan Perilaku Seksual Pranikah. Universitas Batam.

Sari, S. N. (2012) "Perilaku Seksual dan Faktor yang Berhubungan pada Mahasiswa S1 Reguler Fakultas X Universitas Indonesia Tahun 2012."

Sebayang, W. (2018) Perilaku Seksual Remaja. Yogyakarta: Deepublish. Sekretariat Daerah Kabupaten Garut (2010) Internet Sehat.

Siregar, W. W. dan Handayani, D. (2018) "Faktor-Faktor Yang Mempengaruhi Perilaku Seksual Remaja Di Kota Padang," 1(1), hal. 37-44.

Sulianta, F. (2015) Keajaiban Sosial Media. Jakarta: Elex Media Komputindo.

Swarjana, I. K. (2015) Metodologi Penelitian. Yogyakarta: Andi.

Triwibowo, C. (2015) Pengantar Dasar IImu Kesehatan Masyarakat. Yogyakarta: Nuha Medika.

WHO (2018) Adolescent pregnancy. Tersedia pada: https://www.who.int/newsroom/fact-sheets/detail/adolescent- 